\title{
PENGARUH PREVENTIF EKSTRAK DAUN DEWANDARU (Eugenia uniflora. L) TERHADAP KADAR Malondialdehyde (MDA) DAN HISTOPATOLOGI DUODENUM PADA TIKUS PUTIH (Rattus norvegicus) MODEL GASTROENTERITIS INDUKSI
} Escherichia coli

\section{The Preventive Effects of Dewandaru Leaf Extract (Eugenia uniflora) on Malondialdehyde (MDA) Levels and Duodenal Histopathology in White Rat (Rattus norvegicus) \\ Gastroenteritis Models of Escherichia coli Induction Results}

\author{
Aidia Latifatul Fajeria ${ }^{*}$, Sri Murwani, S$^{1}$, Nurina Titisari ${ }^{1}$ \\ Program Studi Pendidikan Dokter Hewan, Fakultas Kedokteran Hewan, Universitas \\ Brawijaya \\ *email: aidiadiadia@gmail.com
}

\begin{abstract}
ABSTRAK
Daun dewandaru (Eugenia uniflora L.) memiliki kandungan utama tannin, flavonoid dan saponin. Kandungan zat yang bersifat antibakteri dan antioksidan pada dewandaru mampu mengurangi penggunaan antibiotik dalam mengobati penyakit gastroenteritis. Gastroenteritis merupakan suatu inflamasi yang terjadi pada saluran pencernaan melibatkan lambung dan usus yang ditandai dengan muntah, diare. Gastroenteritis disebabkan oleh Escherichia coli yang memiliki endotoksin berupa Lipopolisakarida (LPS). Tujuan dari penelitian ini adalah untuk mengetahui pengaruh preventif ekstrak daun dewandaru (Eugenia uniflora L.) dalam menurunkan kadar Malondialdehyde (MDA) dan perbaikan histopatologi duodenum pada tikus putih (Rattus norvegicus) model gastroenteritis hasil infeksi Escherichia coli. Penelitian ini bersifat eksperimental menggunakan Rancangan Acak Lengkap (RAL) dan terdiri dari lima kelompok, yaitu kontrol negatif, kontrol positif (diinjeksi Escherichia coli) dan tiga kelompok preventif (diinjeksi Escherichia coli dan preventif dengan dosis ekstrak daun dewandaru yang berbeda yaitu 300, 400, dan $500 \mathrm{mg} / \mathrm{kg} \mathrm{BB}$ ). Induksi Escherichia coli dengan dosis $1 \times 10^{6} \mathrm{cfu} / \mathrm{mL}$ peroral sebanyak $1 \mathrm{~mL}$ pada hari kedelapan penelitian, yang sebelumnya telah diberi preventif ekstrak daun dewandaru selama 7 hari. Parameter yang diamati dalam penelitian ini adalah histopatologi duodenum dan kadar Malondialdehyde (MDA). Data yang diperoleh dianalisis menggunakan dianalisis secara statistik menggunakan one-way ANOVA $(\alpha=0,05)$. Hasil dari penelitian ini menunjukkan bahwa ekstrak daun dewandaru tidak dapat menghambat adanya kerusakan pada duodenum dan kenaikan kadar MDA. Kesimpulan penelitian ini ekstrak daun dewandaru tidak berpengaruh mencegah gastroenteritis hasil induksi Escherichia coli berdasarkan kerusakan duodenum dan kenaikan kadar MDA.
\end{abstract}

Kata kunci: Gastroenteritis, Escherichia coli, Ekstrak, Daun Dewandaru, Gambaran Histopatologi, Kadar MDA. 
Dewandaru leaves (Eugenia uniflora L.) have the main content of tannins, flavonoids and saponins. The content of antibacterial and antioxidant substances in dewandaru can reduce the use of antibiotics in the treatment of gastroenteritis disease. Gastroenteritis is an inflammation that occurs in the digestive tract involving the stomach and intestines characterized by vomiting, diarrhea. Gastroenteritis is caused by Escherichia coli that has endotoxin in the form of Lipopolysaccharide (LPS). The purpose of this study was to investigate the effect of preventive dewandaru leaves extract (Eugenia uniflora L.) in reducing levels of Malondialdehyde (MDA) and improvement of duodenal histopathology in white rat (Rattus norvegicus) gastroenteritis model of Escherichia coli infection result. This study was experimental using Completely Randomized Design (RAL) and consisted of five groups: negative control, positive control (injected Escherichia coli) and three preventive groups (injected Escherichia coli and preventive dose with different dewandaru leaves extracts of 300,400 , and $500 \mathrm{mg} / \mathrm{kg} \mathrm{BW}$ ). Escherichia coli infection with dose of $1 \times 10^{6} \mathrm{cfu} / \mathrm{mL}$ orally as much as $1 \mathrm{~mL}$ on the eighth day of research, which previously been given preventive dewandaru leaves extract in 7 days. Parameters observed in this study were duodenal histopathology and Malondialdehyde (MDA) levels. The data obtained were analyzed using statistically analyzed using one-way ANOVA $(\alpha=0.05)$. The results of this study indicate that dewandaru leaf extract can't inhibit the deterioration of the duodenum and elevated levels of MDA. The conclusion of this study dewandaru leaf extract has no effect on preventing Escherichia coli induced gastroenteritis based on duodenal damage and elevated MDA levels.

Keywords: Gastroenteritis, Escherichia coli, Dewandaru Leaves, Extract, Duodenal, Histopathology, MDA Levels.

\section{PENDAHULUAN}

Gastroenteritis merupakan infeksi pada lambung, usus halus, dan usus besar yang disebabkan oleh berbagai agen infeksius seperti virus (Norovirus dan Astrovirus), bakteri (E. coli, Salmonella, Campylobacter, Shigella, dan Vibrio cholera) dan parasit (Giardia lamblia). Terjadinya gastroenteritis ditunjukkan dengan gejala klinis seperti diare, abdominal pain, dan vomit (Malone et al., 2014). Infeksi gastroenteritis dapat mengarah ke diare non inflamasi dan inflamasi tergantung pada agen kausatif. Infeksi gastroenteritis biasanya ditransmisikan melalui rute fekal-oral dan makanan yang terkontaminasi. Dari beberapa penyebab, salah satu penyebab yang sering terjadi pada gastroenteritis non inflamasi yaitu Escherichia coli (Ogunseitan and Robbins, 2011).

Gastroenteritis merupakan salah satu penyakit yang masih banyak dijumpai, hal ini dapat dilihat dari hasil survey pada tahun 2010 menyebutkan kasus penyakit ini pada ayam di daerah Jawa Barat mencapai $19-40 \%$. Sedangkan, kerugian ekonomi akibat kematian unggas berupa meningkatnya biaya perawatan dan pengobatan (Supar, 2010).

Escherichia coli merupakan salah satu bakteri flora normal pada saluran pencernaan (Manning, 2010). Escherichia coli berperan dalam pertahanan tubuh melalui kompetisi terhadap nutrisi sehingga pertumbuhan organisme patogen lain terhambat. Selain itu, E.coli menjaga $\mathrm{pH}$ optimal untuk pertumbuhannya sehingga mikroorganisme patogen akan mati pada $\mathrm{pH}$ tersebut karena $\mathrm{pH}$ tersebut tidak sesuai dengan yang dibutuhkan beberapa mikroorganisme patogen untuk bertahan hidup. Namun, E. coli juga dapat menyebabkan infeksi ketika saluran pencernaan terganggu (Sanders, 2012). Escherichia coli dapat menempel ke mukosa (C)2020. Fajeria et al. Open access under CC BY - SA license, doi: 10.20473/mkh.v31i2.2020.74-84 Received: 29-03-2020, Accepted: 10-05-2020, Published online: 29-05-2020 Available at https://e-journal.unair.ac.id/MKH/index 
intestinal dan mensekresikan enterotoksin atau sitotoksin (Ericson et al., 2008). Lipopolysaccharides (LPS) merupakan toksin yang dimiliki E. coli. Pelepasan LPS dapat menyebabkan inflamasi pada saluran gastrointestinal. Inflamasi yang terjadi pada mukosa intestin dapat menyebabkan gangguan absorpsi makanan (Chaudhary and Adamson, 2016). Pengeluaran cairan dan elektrolit yang berlebihan karena kerusakan pada mukosa intestin menyebabkan diare (Walker and Whittlesea, 2012).

Menurut Watson and Preedy (2013), tanpa adanya inflamasi, penyembuhan tidak akan terjadi. Inflamasi dapat diklasifikasikan menjadi inflamasi akut dan kronis. Sistem imun pada inflamasi akut merespon karakteristik agen infeksius atau debris yang disebabkan oleh luka, dengan menghasilkan gejala seperti pembengkakan, sakit, kemerahan, imobilitas, dan panas. Munculnya gejala tersebut disebabkan oleh peningkatan produksi leukosit dalam merespon jaringan yang terpapar antigen. Selama inflamasi kronis, jaringan akan meningkatkan produksi reactive oxygen species (ROS) sebagai biomarker inflamasi yang dapat menghasilkan stres oksidatif.

Stres oksidatif didefinisikan sebagai ketidakseimbangan antara produksi radikal bebas dan mekanisme antioksidan. Produksi radikal bebas yang berlebihan atau kurangnya antioksidan akan mengarah ke stres oksidatif. Radikal bebas merupakan atom atau molekul dengan elektron yang tidak berpasangan sehingga menyebabkan reaktifitas tinggi. Apabila mekanisme antioksidan gagal menangani ROS, makromolekul seperti lipid, asam nukleat, dan protein maka akan beresiko teroksidasi. Hal ini mengarah ke disintegrasi struktur, malfungsi, bahkan perubahan pada epitop dan pengenalan oleh sistem imun. Lipid sangat sensitif terutama terhadap kerusakan oksidatif. Jumlah produk peroksidasi lipid terutama malondialdehyde (MDA) dapat diukur untuk menghitung keparahan stres oksidatif (Watson, 2015).

Antioksidan berfungsi mencegah terhimpunnya senyawa-senyawa oksidan, menurunkan reaksi oksidasi, memutus, menghambat, menghentikan dan menstabilkan radikal bebas. Beberapa penelitian menyebutkan bahwa kelompok senyawa flavonoid memiliki aktivitas sebagai donor hidrogen dan mereduksi radikal bebas di dalam jaringan (Prakash, 2001). Fungsi senyawa tanin dan saponin sebagai antibakteri dapat menghambat perkembangan bakteri, sehingga menurunkan derajat kerusakan jaringan yang ditandai dengan berkurangnya hemoragi dan membantu sel epitel untuk melakukan proliferasi secara normal tanpa gangguan dari toksin bakteri (Pringgoutomo dkk, 2002).

Berdasarkan latar belakang yang telah diuraikan, penelitian ini bertujuan untuk mengetahui pengaruh ekstrak daun dewandaru (Eugenia uniflora) terhadap kadar MDA dan histopatologi duodenum pada Tikus (Rattus norvegicus) model gastroenteritis sebagai tindakan pencegahan terhadap gastroenteritis pada hewan.

\section{MATERI DAN METODE}

Alat dan Bahan

Peralatan yang dipergunakan dalam penelitian ini, antara lain bak pemeliharaan hewan coba, tempat pakan, tempat minum, timbangan tikus, sonde lambung. Preparasi organ duodenum membutuhkan seperangkat alat bedah minor, silet, hand glove, pot organ dan masker. Pembuatan preparat histopatologi membutuhkan pisau scalpel, pinset, freezer, mesin microtome, pisau microtome, inkubator, object glass, cover glass, dan mikroskop cahaya. Pengukuran kadar MDA membutuhkan kuvet, spektrofotometri, mortar, tabung eppendorf, pipet tetes, mikro pipet, mikro tube, lemari pendingin, seperangkat alat sentrifugasi 
(tabung sentrifugasi, alat sentriugasi), inkubator, vortex, tissue.

Bahan yang digunakan dalam penelitian ini adalah tikus putih (Rattus norvegicus) berumur 8-12 minggu dengan berat 150-200 gram, daun dewandaru (Eugenia uniflora), pakan dan air minum hewan coba, bakteri E. coli. Bahan untuk pembuatan preparat histopatologi adalah organ duodenum direndam pada formalin $10 \%, \mathrm{NaCl}$ fisiologis $0,9 \%$, formalin $10 \%$, etanol absolut $96 \%$, aquades steril, alkohol, etanol bertingkat (70\%, 80\%, 90\%, 95\% dan etanol absolut), xylol, parafin dan pewarna histopatologi Hematoxylen-Eosin. Bahan untuk pengukuran kadar MDA adalah PBS-azida 1\%, larutan stok MDA (malondialdehyde tetrabutylammonium salt) dan $8 \mu \mathrm{m} / \mathrm{ml}, 100 \mu \mathrm{l}$ TCA 10\%, $250 \mu \mathrm{l} \mathrm{HCl} 1 \mathrm{~N}$, Na-Thio $1 \%$.

\section{Persiapan Hewan Coba}

Hewan coba yang digunakan adalah 20 ekor tikus putih (Rattus norvegicus) strain Wistar, berjenis kelamin jantan, berumur 2-3 bulan, dan memiliki rata-rata bobot badan 200 gram. Hewan coba diaklimatisasi selama 7 hari, diberi pakan standar dan air minum secara ad libitum. Hewan coba dibagi menjadi 5 kelompok perlakuan, yaitu kelompok A (kontrol negatif) yang terdiri dari tikus tanpa induksi dan preventif, kelompok B (kontrol positif) adalah tikus yang diinduksi Esherichia coli dan tidak diberi preventif, kelompok $\mathrm{C}$ tikus yang diinduksi $E$. coli dan diberi preventif ekstrak daun dewandaru (Eugenia uniflora) dengan dosis $300 \mathrm{mg} / \mathrm{kg} \mathrm{BB}$, kelompok D tikus yang diinduksi $E$. coli dan diberi preventif ekstrak daun dewandaru dengan dosis 400 $\mathrm{mg} / \mathrm{kg} \mathrm{BB}$, dan kelompok $\mathrm{E}$ tikus yang dinduksi E. coli dan diberi preventif ekstrak daun dewandaru dengan dosis $500 \mathrm{mg} / \mathrm{kg} \mathrm{BB}$. Setiap kelompok perlakuan terdiri dari 4 ekor tikus. Penggunaan hewan coba dalam penelitian ini telah mendapatkan persetujuan laik etik dari Komisi Etik Penelitian Universitas Brawijaya No. 670-KEP-UB.

\section{Tata laksana Pembuatan Hewan Coba Model Gastroenteritis}

Pembuatan hewan coba model gastroenteritis dilakukan dengan menginjeksikan Escherichia coli standar Mc Farland 1 (3 x $\left.10^{8} \mathrm{cfu} / \mathrm{mL}\right)$ sebanyak $10^{6}$ $\mathrm{CFU} / \mathrm{ml}(1 \mathrm{~mL} /$ hari dosis tunggal $)$ pada 16 ekor tikus dari 4 kelompok perlakuan (kelompok B, C, D, dan E) (Astawan dkk., 2011). Injeksi Escherichia coli dilakukan setiap hari selama 7 hari dengan cara sonde lambung

\section{Pembuatan Sediaan Ekstrak Daun Dewandaru (Eugenia uniflora)}

Prosedur pembuatan ekstrak daun dewandaru (Eugenia uniflora) menggunakan metode maserasi. Proses ekstraksi dilakukan menggunakan etanol 70\%, hal tersebut dikarenakan zat aktif seperti flavonoid yang terkandung didalam daun dewandaru akan terlarut dalam etanol. Etanol dengan nama lain etil alkohol merupakan pelarut yang sering digunakan dalam ekstraksi tanaman. Sebagian besar senyawa dengan berat molekul rendah seperti saponin, dan flavonoid larut didalam pelarut etanol. Daun dewandaru ditimbang sebanyak $100 \mathrm{~g}$ dan dilakukan pembasahan dengan pelarut etanol $70 \%$ sebanyak $100 \mathrm{ml}$. Masukkan serbuk yang telah dibasahi dengan pelarut ke dalam toples, diratakan dan sambil ditambahkan pelarut etanol $70 \%$ sampai terendam (pelarut yang digunakan minimal 2 kali berat atau lebih). Pelarut yang ditambahkan sebanyak $500 \mathrm{ml}$. Tutup toples dengan rapat selama 24 jam. Dan di shaker di atas shaker digital rpm 50 (Materia Medica, 2017).

Ekstrak cair disaring dengan penyaring kain. Ekstrak tersebut ditampung dalam Erlenmeyer. Ampas dari ekstrak dimasukkan lagi dalam toples dan ditambahkan pelarut sampai terendam (minimal pelarut $5 \mathrm{~cm}$ diatas permukaan), dalam hal ini digunakan $500 \mathrm{ml}$ 
pelarut etanol. Biarkan 24 jam diatas shaker dengan kecepatan $50 \mathrm{rpm}$. Hasil ekstrak cair pertama dan kedua dijadikan satu dan diuapkan dengan menggunakan rotary evaporator. Diperlukan waktu 2 jam untuk evaporasi. Ekstrak yang dihasilkan dievaporasi/diuapkan diatas water bath selama 2 jam. Dari $100 \mathrm{~g}$ serbuk daun dewandaru yang diekstraksi dengan menggunakan pelarut etanol 70\% sebanyak $1 \mathrm{~L}$ dihasilkan ekstrak 20 ml (Materia Medica, 2017).

Tata Laksana Pemberian Preventif Ekstrak Daun Dewandaru (Eugenia uniflora)

Pemberian preventif dilakukan pada hari ke 8 sampai hari ke 14 . Ekstrak daun dewandaru diberikan pada kelompok preventif $\mathrm{C}, \mathrm{D}$, dan $\mathrm{E}$ secara per-oral melalui sonde lambung. Ekstrak daun dewandaru terlebih dahulu disuspensikan ke dalam PBS sebanyak $1 \mathrm{~mL}$ sebelum diberikan ke hewan coba. Pemberian terapi dilakukan 1 kali sehari selama 7 hari.

\section{Euthanasi Hewan Coba dan Isolasi Organ}

Euthanasi pada tikus dilakukan pada hari ke 22 setelah seluruh perlakuan. Euthanasi tikus dilakukan dengan cara dislokasi leher kemudian direbahkan pada posisi rebah dorsal. Lalu dilakukan pembedahan pada bagian abdomen dan pengisolasian organ duodenum. Organ duodenum dibilas dengan $\mathrm{NaCl}$-fisiologis 0,9\%, kemudian dimasukkan pada plastik klip (Junquiera and Carneiro, 2007).

\section{Pengukuran Kadar MDA Duodenum}

Jaringan duodenum diambil dari setiap sampel sebanyak 0,1 gram dan dipotong kecilkecil lalu digerus dalam mortar. Kemudian ditambahkan $1 \mathrm{~mL}$ aquades. Homogenant yang terbentuk dipindahkan ke dalam microtube dan ditambahkan $100 \mu \mathrm{L}$ TCA, $250 \mu \mathrm{L} \mathrm{HCl} 1 \mathrm{~N}$, dan $100 \mu \mathrm{L}$ Na-thio 1\%. Pada setiap penambahan reagen, larutan dihomogenkan dengan vortex. Larutan lalu diinkubasi dalam waterbath pada suhu $100^{\circ} \mathrm{C}$ selama 20 menit dan dibiarkan dingin pada suhu ruang. Kemudian larutan disentrifugasi dengan kecepatan 3500 rpm selama 10 menit. (C)2020. Fajeria et al. Open access under CC BY - SA license, doi: 10.20473/mkh.v31i2.2020.74-84 Received: 29-03-2020, Accepted: 10-05-2020, Published online: 29-05-2020

Available at https://e-journal.unair.ac.id/MKH/index
Supernatan yang terbentuk diambil dan ditambahkan aquades sebanyak $3500 \mu \mathrm{L}$. Kemudian larutan tersebut diukur absorbansinya dengan panjang gelombang 532 $\mathrm{nm}$ dan diplotkan pada kurva standar yang telah dibuat untuk menghitung konsentrasi sampel (Repetto et al., 2012).

Pembuatan Preparat Histopatologi Duodenum dengan Pewarnaan HE

Proses pembuatan preparat histopatologgi terdiri dari fiksasi, dehidrasi dan infiltrasi, penjernihan, infiltrasi paraffin, embedding, sectioning, penempelan di gelas objek, dan pewarnaan. Fiksasi dilakukan dengan cara jaringan dimasukkan ke dalam larutan PFA 4\%. Fiksasi dilakukan untuk mencegah kerusakan pada jaringan, menghentikan proses metabolisme dan mengeraskan materi yang lunak agar jaringan dapat diwarnai. Dehidrasi dilakukan dengan alkohol bertingkat dari konsentrasi $70 \% 24$ jam, etanol $80 \% 2$ jam, etanol 90\%, 95\%, dan etanol absolut 20 menit. Penjernihan dengan cara direndam jaringan dalam larutan xylol I selama 20 menit dan xylol II selama 30 menit. Infiltrasi dan embeeding dilakukan dengan blok parafin pada inkubator bersuhu $56-58^{\circ} \mathrm{C}$. Cetakan dijepit dalam mikrotom dan jaringan dipotong ketebalan $5 \mu \mathrm{m}$. Sediaan disimpan dalam inkubator suhu $38-40{ }^{\circ} \mathrm{C}$ selama 24 jam. Deparafinasi dilakukan dengan xylol I dan II. Rehidrasi dengan menggunakan etanol absolut, 95\%,90\%,80\%,70\%. Kemudian dicuci dengan air mengalir. Pewarnaan Hematoxylin 10 menit lalu dicuci dengan air mengalir. Pewarnaan eosin dilakukan selama 5 menit. Dehidrasi dilakukan dengan etanol absolut, 95\%,90\%,80\%, 70\%. Mountain dengan entellan. Pengamatan histopatologi dilakukan dengan menggunakan mikroskop cahaya (Junquiera and Carneiro, 2007).

\section{Analisis Data}

Penelitian ini menggunakan analisis kuantitatif statistik OneWay ANOVA terhadap kadar MDA dan dilanjutkan dengan uji Tukey menggunakan $a=5 \%$. Gambaran histopatologi 
jaringan duodenum diamati secara deskriptif melalui pengamatan terhadap adanya erosi epitel pada vili dan sel-sel radang

\section{HASIL DAN PEMBAHASAN

$\begin{array}{lccc}\text { Pengaruh } & \text { Preventif } & \text { Ekstrak } & \text { Daun } \\ \text { Dewandaru } & \text { Terhadap } & \text { Kadar } \\ \text { Malondialdehyde } & \text { (MDA) } & \text { Duodenum } & \text { Tikus } \\ \text { Model Gastroenteritis } & & \end{array}$

Hasil pengukuran MDA menggunakan metode Thiobarbituric Acid (TBA) menunjukkan bahwa pemberian ekstrak daun dewandaru secara preventif dapat menurunkan kadar MDA duodenum pada tikus model gastroenteritis. Pada tikus normal (kontrol negatif) terukur kadar MDA duodenum sebesar 0,536 ng/mL. Dalam keadaan normal, MDA akan tetap dihasilkan selama terjadinya biosintesis prostaglandin dalam sel. Malondialdehyde (MDA) juga dihasilkan sebagai produk dari peroksidasi lipid terutama polyunsaturated fatty acid (PUFA), yang merupakan reaksi berantai akibat abstraksi hidrogen atau penambahan oksigen radikal dan akan mengakibatkan kerusakan oksidatif pada PUFA yang banyak terdapat pada membran sel (Repetto et al., 2012).

Berdasarkan hasil Post Hoc dengan uji Tukey didapatkan hasil bahwa kelompok preventif P1 (300 mg/kg BB), P2 (400 mg/kg BB), dan P3 (500 mg/ $\mathrm{kg} \mathrm{BB}$ ) tidak berbeda signifikan dibandingkan kelompok $\mathrm{K}+$ (kontrol positif) $(p<0,05)$. Jika dibandingkan dengan kelompok K- (Kontrol negatif), kelompok preventif P1 (300 mg/kg BB), P2 (400 mg/kg $\mathrm{BB})$, dan P3 (500 mg/kg BB) memiliki perbedaan yang signifikan. Hal ini menunjukkan bahwa semua kelompok preventif tidak dapat menurunkan kadar MDA tikus putih (Rattus norvegicus) model gastroenteritis dibandingkan dengan kelompok kontrol positif. Pada preventif antar kelompok P1, P2, dan P3 menunjukkan rentang perbedaan efek preventif yang cukup sedikit. Namun, hanya kelompok P1 (300 mg/kg BB) yang berhasil menurunkan kadar MDA jika dibandingkan pada kelompok K- (kontrol negatif). Perbedaan nilai antar perlakuan dapat dilihat pada Tabel 5.1 berikut ini.
Tabel 5.1 Rata-rata, Standar Deviasi, dan Hasil Uji Tukey Kadar MDA

\begin{tabular}{ll}
\hline Perlakuan & $\begin{array}{l}\text { Rata-Rata } \\
\text { kadar MDA }\end{array}$ \\
\hline $\begin{array}{l}\text { Kontrol negatif (A) } \\
\text { Kontrol positif (B) }\end{array}$ & $0,536 \pm 0,14^{\mathrm{a}}$ \\
$\begin{array}{l}\text { Dosis terapi } 300 \mathrm{mg} / \mathrm{kg} \mathrm{BB} \\
\text { (C) }\end{array}$ & $0,848 \pm 0,09^{\mathrm{b}}$ \\
$\begin{array}{l}\text { Dosis terapi } 400 \mathrm{mg} / \mathrm{kg} \\
\text { BB(D) }\end{array}$ & $0,874 \pm 0,05^{\mathrm{b}}$ \\
$\begin{array}{l}\text { Dosis terapi } 500 \mathrm{mg} / \mathrm{kg} \text { BB } \\
\text { (E) }\end{array}$ & $0,898 \pm 0,05^{\mathrm{b}}$ \\
\hline
\end{tabular}

Keterangan: notasi yang berbeda
menunjukkan perbedaan yang signifikan antar perlakuan $(\mathrm{p}<0,05)$.

Kelompok $\mathrm{K}(+)$ menunjukkan jumlah kadar MDA yang lebih tinggi dari pada kelompok K(-) dan menunjukkan adanya perbedaan yang signifikan $(\mathrm{p}<0,05)($ Tabel 5.1). Tingginya kadar pada kelompok $\mathrm{K}(+)$ terjadi akibat kerusakan sel-sel di duodenum yang disebabkan adanya infeksi dari bakteri Escherichia coli. E. coli merupakan bakteri gram negatif yang mempunyai endotoksin berupa LPS pada membran sel. Lipopolisakarida (LPS) atau endotoksin akan disekresikan oleh E. coli ketika bakteri tersebut lisis. Lipopolisakarida (LPS) kemudian akan berikatan dengan LBP membentuk kompleks LPS-LBP. Lipopolisakarida terikat pada reseptor spesifik CD14 dan TLR4 pada makrofag. Kompleks LPS-LBP mentransfer LPS ke CD14 yang terdapat di permukaan sel makrofag. Setelah berikatan dengan LPS, CD14 akan berinteraksi dengan TLR4 menyebabkan aktivasi dari NFkB (Hongwei et al., 2005). Nuclear Factor-kB (NF$\mathrm{kB})$ merupakan faktor trankripsi pada makrofag yang akan meningkatkan produksi dari sitokin dan mediator inflamasi. Makrofag yang teraktivasi mensekresikan sitokin proinflamasi IL-1, IL-6 dan TNF-a. Pelepasan sitokin proinflamasi pada jaringan akan menyebabkan sel memproduksi oksigen toksik untuk proses respiratory burst yaitu reactive oxygen species (ROS) (Short, 2004).

Menurut Arief (2008), suatu keadaan dimana tingkat reactive oxygen species (ROS) 
melebihi pertahanan antioksidan endogen akan menyebabkan stress oksidatif. Keadaan ini mengakibatkan kelebihan radikal bebas, dan akan bereaksi dengan lemak, protein, asam nuklear seluler, sehingga terjadi kerusakan lokal dan disfungsi organ tertentu. Kerusakan oksidatif yang ditimbulkan akibat tingginya produksi ROS ditandai dengan diproduksinya senyawa aldehida reaktif yaitu MDA. Kelompok perlakuan dari pemberian dosis ekstrak daun dewandaru $300 \mathrm{mg} / \mathrm{kg} \mathrm{BB}, 400$ $\mathrm{mg} / \mathrm{kg}$ BB dan $500 \mathrm{mg} / \mathrm{kg}$ BB meningkat dibandingkan dengan kontrol negatif. Pada kontrol positif meningkat sebesar 76,82\% lebih tinggi dibandingkan dengan kontrol negatif.

Berdasarkan skrining fitokimia daun tanaman dewandaru mengandung flavonoid, tanin, dan saponin. Flavonoid dan tanin digunakan sebagai antioksidan eksogen dan antibakteri. Flavonoid akan berikatan dengan DNA bakteri sehingga menyebabkan kerusakan permeabilitas dinding sel, mikrosom, dan lisosom bakteri. Selain itu flavonoid berperan sebagai antioksidan karena memiliki gugus hidroksil yang terikat pada karbondioksida sehingga dapat menangkap radikal bebas dengan menyumbangkan satu atom hidrogen. Sementara itu senyawa tanin dapat menginaktivasi adhesi sel mikroba sehingga bakteri tidak dapat melakukan perlekatan pada sel epitel dan menstimulasi sel-sel fagosit yang berperan dalam respon imun seluler (Utami et al, 2007).

Malondialdehida (MDA) dapat terbentuk apabila reactive oxygen species (ROS) bereaksi dengan komponen asam lemak dari membran sel sehingga terjadi reaksi berantai yang dikenal dengan peroksidasi lipid. Peroksidasi lipid merupakan proses oksidasi asam lemak tak jenuh rantai panjang yang menyebabkan terputusnya rantai asam lemak menjadi berbagai senyawa toksik dan juga menyebabkan kerusakan pada membran sel karena menghasilkan produk akhir MDA (Yunus, 2001). MDA dapat digunakan sebagai indeks peroksidasi lipid dan alat ukur aktivitas radikal bebas secara tidak langsung (Suryohudoyo, 2000). Infeksi Escherichia coli pada hewan coba dapat meningkatkan radikal bebas dalam tubuh sehingga menyebabkan stress oksidatif yang memicu peroksidasi lipid. Jadi, kadar MDA paling tinggi dimiliki oleh kelompok tikus kontrol positif.

Hasil analisis kadar MDA pada penelitian ini menunjukkan bahwa kelompok tikus gastroenteritis (kontrol positif) kadar MDA mengalami peningkatan karena adanya infeksi, sedangkan kontrol negatif mengalami penurunan. Dosis kelompok P1, P2, dan P3 mengalami peningkatan karena kelompok perlakuan tidak mampu untuk mencegah kerusakan pada saat kerusakan jaringan sehingga MDA meningkat. Tingginya kadar MDA terjadi akibat stress oksidatif yang secara tidak langsung menunjukkan tingginya radikal bebas. Radikal bebas yang terbentuk tidak diimbangi oleh antioksidan endogen, sehingga memicu terjadinya peroksidasi lipid dengan produk akhir MDA. Pemberian ekstrak daun dewandaru sebagai preventif kurang mampu menurunkan tingkat stress oksidatif karena kurangnya dosis yang diberikan. Dosis perlakuan $300 \mathrm{mg} / \mathrm{kg}$ BB dan $400 \mathrm{mg} / \mathrm{kg}$ BB dan $500 \mathrm{mg} / \mathrm{kg}$ BB dengan ekstrak daun dewandaru tidak berbeda nyata dengan kontrol positif yang dinilai belum mampu untuk menurunkan kadar MDA sehingga diperlukan dosis yang lebih tinggi.

\section{Pengaruh Preventif Ekstrak Daun Dewandaru Terhadap Gambaran Histopatologi Duodenum Tikus Model Gastroenteritis}

Pengamatan parameter histopatologi duodenum dilakukan untuk mengetahui gambaran inflamasi berdasarkan histopatologi. Seperti struktur epitel, sel-sel radang, dan sel goblet pada masing-masing sampel dilakukan menggunakan mikroskop dengan perbesaran 100x, dan 400x yang ditunjukkan pada Gambar A sampai dengan Gambar $\mathbf{E}$ berikut ini.

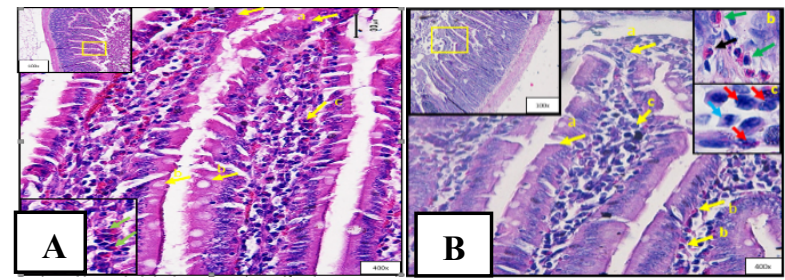

(C)2020. Fajeria et al. Open access under CC BY - SA license, doi: 10.20473/mkh.v31i2.2020.74-84 Received: 29-03-2020, Accepted: 10-05-2020, Published online: 29-05-2020

Available at https://e-journal.unair.ac.id/MKH/index 


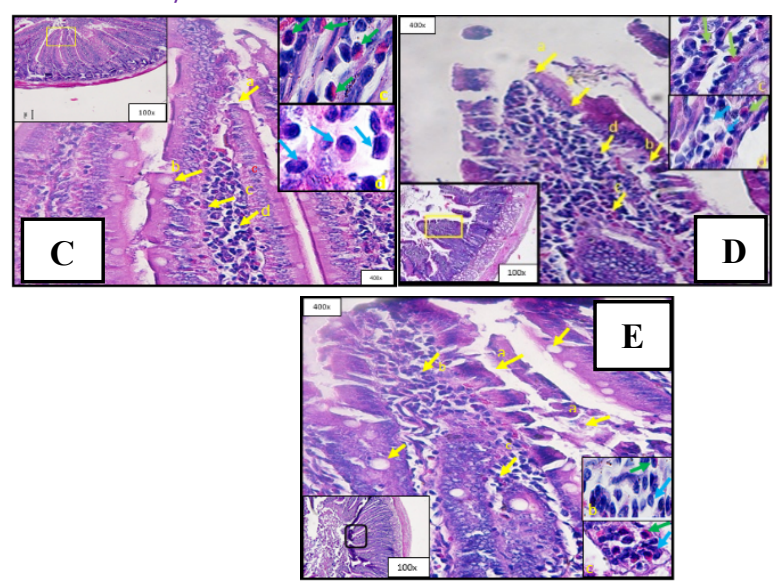

Gambar 1. Gambaran Histopatologi duodenum (perbesaran 100x dan 400x). Terjadi infiltrasi sel radang, hipertrofi sel goblet dan struktur sel epitel yang terjadi erosi pada kelompok terapi C, D, dan E dibandingkan kelompok B (kontrol positif).

Keterangan: Tanda panah gambar B, C, D dan E menujukkan adanya kelainan (daerah yang abnormal).

Hasil penelitian pengaruh preventif ekstrak daun dewandaru terhadap gambaran histopatologi duodenum dengan pewarnaan hematoxyline-eosin (HE) dianalisa secara deskriptif menggunakan mikroskop cahaya dengan perbesaran 100x dan 400x dengan mengamati struktur vili, sel epitel dan sel goblet (Gambar A sampai dengan Gambar E). Gambaran histologi duodenum normal terdiri dari empat lapisan, yaitu tunika mukosa, tunika submukosa, muskularis eksterna, dan tunika serosa (Eroschenko, 2008).

Tunika mukosa terdapat vili, sel epitel, dan sel goblet. Kelompok tikus sehat (Gambar A) menunjukkan gambaran histologi duodenum tikus sehat yang tanpa diberi perlakuan induksi E. coli. Terlihat tidak ada kerusakan pada struktur vili, sel epitel dan terdapat sel goblet. Gambaran histopatologi kontrol negatif dan kontrol positif yang diamati adalah perubahan pada struktur vili, sel epitel, dan sel goblet. Pengamatan dilakukan untuk mengetahui perubahan gambaran histopatologi kontrol positif setelah diberi perlakuan induksi E.coli secara peroral.
Kelompok kontrol positif (Gambar B) menunjukkan adanya kerusakan pada struktur jaringan duodenum dibandingkan dengan kontrol negatif. Deretan sel epitel kolumner pada bagian mukosa mengalami erosi dan sebagian ada yang menghilang, berkurangnya sel goblet karena adanya erosi epitel dan terdapat infiltrasi sel radang karena terjadi kerusakan yang disebabkan adanya E. coli sehingga menyebabkan inflamasi. Gambaran histopatologi duodenum yang diberi perlakuan ekstrak daun dewandaru dengan dosis preventif $300 \mathrm{mg} / \mathrm{kg} \mathrm{BB}, 400 \mathrm{mg} / \mathrm{kg} \mathrm{BB}$, $500 \mathrm{mg} / \mathrm{kg}$ BB menunjukkan adanya kerusakan terhadap susunan sel epitel kolumner pada mukosa jika dibandingkan dengan kontrol negatif. Erosi epitel yang masih ditemukan dan sel radang yang ditemukan juga jumlahnya masih banyak seiring dengan volume pemberian ekstrak daun dewandaru yang meningkat (Gambar C sampai dengan Gambar E). Kelompok perlakuan 1 (Gambar C) yang diberi ekstrak daun dewandaru dengan dosis $300 \mathrm{mg} / \mathrm{kg} \mathrm{BB}$, terlihat adanya erosi vili, terdapat sel goblet, ditemukan sedikit sel radang neutrofil maupun makrofag dan gambaran epitel vili duodenum yang menyerupai normal. Kelompok tikus putih perlakuan 2 (Gambar D) yang diberi ekstrak daun dewandaru $400 \mathrm{mg} / \mathrm{kg} \mathrm{BB}$, struktur sel epitel mengalami erosi pada beberapa area, sel goblet mengalami hipertrofi dan infiltrasi sel radang makrofag dan neutrofil yang lebih banyak. Kelompok perlakuan 3 (Gambar E) yang diberikan ekstrak daun dewandaru 500 $\mathrm{mg} / \mathrm{kg} \mathrm{BB}$, terlihat adanya struktur sel epitel mengalami erosi, sel goblet mengalami hipertrofi, dan terdapat infiltrasi sel radang makrofag dan neutrofil. Kelompok perlakuan 1 mengalami kerusakan histopatologi yang lebih sedikit dibandingkan P2 dan P3. Kerusakan histopatologi duodenum yang paling rusak pada perlakuan 2 dibandingkan perlakuan 3 .

Geboes (2003) mengatakan bahwa inflamasi pada duodenum ditandai dengan kerusakan pada lapisan mukosa, yaitu pada 
bagian vili dan hilangnya sel goblet. Sel goblet yang hilang ini disebabkan karena adanya erosi epitel yang menyebabkan berkurangnya sel goblet pada kelompok kontrol positif (Gambar B). Sel goblet mensintesis dan mensekresikan mukus glikoprotein berbentuk gel untuk melindungi sel-sel epitelium intestinal dari invasi bakteri. Aktivasi sitokin yang dilepaskan oleh sel Th-2 merangsang sel goblet. Pada usus yang terinfeksi berat, dapat ditemukan jumlah sel goblet yang sangat banyak. Hal ini menunjukkan adanya infeksi bakteri maka sel goblet akan mengalami proliferasi yang bertujuan mempertahankan hidup dari infeksi (Balqis et al., 2015).

Infeksi E.coli yang bersifat patogen pada kelompok kontrol positif akan menempel pada lapisan mukosa sehingga dapat menyebabkan erosi sel-sel epitel permukaan dan peradangan pada usus halus. Selain itu, pada kelompok kontrol positif juga ditemukan adanya infiltrasi sel radang, yaitu neutrofil, monosit dan limfosit. Kumar et al (2013) menyebutkan bahwa enterotoksin yang dihasilkan oleh $E$. coli berupa toksin labil panas dan toksin stabil panas. Enterotoksin mengaktivasi berbagai mediator inflamasi seperti komplemen dan sitokin. Mediator inflamasi tersebut menyebabkan vasodilatasi pembuluh darah serta meningkatkan permeabilitas pembuluh darah. Akibatnya, sel-sel inflamasi, salahsatunya neutrofil dan limfosit menuju jaringan usus yang terinfeksi untuk melakukan perlawanan sistem imun dengan bakteri patogen (Gambar B).

Kelompok perlakuan yang
mendapatkan preventif ekstrak daun dewandaru pada (Gambar $\mathbf{C}$ sampai dengan Gambar E) nampak masih terjadi kerusakan struktur epitel vili, ini dikarenakan pemberian preventif ekstrak daun dewandaru yang berperan sebagai antibakteri dan antioksidan kurang mampu menghambat kerusakan struktur epitel vili. Adanya perubahan pada jaringan antara kelompok kontrol dan perlakuan disebabkan oleh adanya zat antioksidan seperti flavonoid (Supratanda, dkk., 2014).
Mekanisme senyawa flavonoid yang mungkin terjadi pada kelompok perlakuan adalah zat flavonoid dapat menetralisir senyawa radikal bebas dan mencegah terjadinya reaksi berantai dengan cara mendonorkan elektronnya kepada radikal bebas sehingga menjadi stabil. Selain itu antioksidan akan mengurangi oksidatif lebih lanjut dari asam lemak pada fosfolipid sehingga regenerasi dapat berlangsung lebih cepat (Tappi, 2013). Daun dewandaru memiliki aktivitas sebagai antioksidan secara in vitro, dengan mekanisme kerja menangkap radikal bebas yang merupakan salah satu penyebab kerusakan sel. Hasil penelitian tersebut menunjukkan aktivitas penangkap radikal pada ekstrak etanol, etil asetat dan kloroform dengan nilai $I C_{50}$ (Inhibitory Concentration) (Utami dkk., 2005). Penelitian lain juga menyatakan bahwa daun dewandaru memiliki aktivitas menangkap radikal bebas dengan nilai $I C_{50}$ ekstrak heksana, kloroform, etil asetat dan air (Velaquez et al., 2003).

Cotran et al (2003), menyebutkan bahwa toksin bakteri, seperti LPS pada bakteri gram negatif dapat memicu terbentuknya kompleks LPS-LBP dan menggertak aktivasi komplemen. Komplemen berperan sebagai stimulus bagi sel-sel radang polimorf (PMN) dan makrofag. Polimorfonuklear (PMN) dan makrofag dalam memproses antigen akan menginduksi terjadinya inflamasi pada jaringan. Reaksi inflamasi memunculkan tanda klinis berupa perubahan vaskuler yaitu vasodilatasi, sehingga terjadi peningkatan aliran darah setempat dan perubahan mikrovaskuler yaitu peningkatan permeabilitas, sehingga memungkinkan sel endotel pecah dan terjadi akumulasi eritrosit pada jaringan (hemoragi) (Arimbi dkk., 2015). Gambaran histopatologi duodenum berkaitan dengan dosis preventif yang diberikan. Penyebab destruksi epitel duodenum adalah toksin bakteri yang menimbulkan peningkatan metabolisme sel tubuh sehingga sel menggalami stress oksidatif yang memicu peroksidasi lipid dengan produk akhir peningkatan MDA. Fungsi senyawa flavonoid sebagai antioksidan dapat meredam terjadinya stress oksidatif yang diukur melalui 
penurunan kadar MDA, sehingga derajat kerusakan jaringan dapat menurun.

Fungsi senyawa tanin dan saponin sebagai antibakteri dapat menghambat perkembangan bakteri, sehingga menurunkan derajat kerusakan jaringan yang ditandai dengan berkurangnya hemoragi dan memberi kesempatan sel epitel untuk melakukan proliferasi secara normal tanpa gangguan dari toksin bakteri. Sel epitel duodenum beregenerasi secara normal dalam waktu tiga sampai enam hari. Kemampuan regenerasi sel didasarkan pada jenis sel. Sel epitel traktus digestivus termasuk sel yang bersifat labil, dimana sel ini memiliki kemampuan regenerasi yang tinggi. Sel labil mempunyai waktu istirahat yang singkat, sehingga sel yang hilang dapat menstimuli sel baru pada fase istirahat untuk memasuki masa mitosis sel (Pringgoutomo dkk., 2002). Proliferasi sel tersebut dapat memperbaiki struktur villi duodenum.

Pada penelitian ini hasil histologi duodenum P1, P2 dan P3 (Gambar C-Gambar E) dengan dosis $300 \mathrm{mg} / \mathrm{kg}$, BB, $400 \mathrm{mg} / \mathrm{kg} \mathrm{BB}$, $500 \mathrm{mg} / \mathrm{kg}$ BB masih kurang efektif. Pemberian ekstrak daun dewandaru belum mampu menghambat sintesis dinding sel bakteri, sehingga sel epitel tidak dapat berkesempatan untuk berproliferasi lebih baik. Seharusnya pemberian preventif juga akan menguatkan fungsi antioksidan tubuh sehingga sel tubuh tetap dapat mengimbangi jumlah radikal bebas yang timbul akibat infeksi E. coli. Pada penelitian ini terbukti bahwa preventif ekstrak daun dewandaru belum mampu mencegah kerusakan jaringan duodenum pada tikus yang diinfeksi E. coli.

\section{KESIMPULAN}

Dari hasil penelitian ini dapat disimpulkan bahwa pemberian ekstrak daun dewandaru (Eugenia uniflora $L$ ) dengan dosis $300 \mathrm{mg} / \mathrm{kg} \mathrm{BB}, 400 \mathrm{mg} / \mathrm{kg} \mathrm{BB}$, dan $500 \mathrm{mg} / \mathrm{kg}$ $\mathrm{BB}$ tidak dapat digunakan menurunkan kadar malondialdehyde (MDA) duodenum dan belum optimal dalam mencegah kerusakan gambaran histopatologi jaringan duodenum dibandingkan dengan kelompok kontrol positif. Perlu dilakukan penelitian lebih lanjut berkaitan dengan penentuan dosis preventif ekstrak daun dewandaru (Eugenia uniflora L) yang lebih tepat pada kondisi gastroenteritis.

\section{UCAPAN TERIMA KASIH}

Terima kasih kepada segenap staf Laboratorium UPT Materia Medica, Laboratorium Faal FK UB, Laboratorium Mikrobiologi FK UB serta Laboratorium Parasitologi FK UB yang telah membantu menyiapkan fasilitas yang diperlukan selama penelitian berlangsung.

\section{DAFTAR PUSTAKA}

Arimbi, A.A., R. Darsono, H. Plumeriastuti, T.V. Widiyatno dan D. Legowo. 2015. Buku Ajar Patologi Umum Veteriner Edisi 2. Airlangga Press. Surabaya.

Astawan, M., T. Wresdiyati, I.I Arief, dan E. Suhesti. 2011. Gambaran Histopatologi Tikus Putih (Rattus norvegicus) yang Diinfeksi Escherichia coli Enteropatogenik dan Diberikan Probiotik [Skripsi]. Fakultas Kedokteran Hewan. Institut Pertanian Bogor.

Balqis, U., M. Hanafiah, J. Connie, M. Nur, A. Siti, dan F. Yudha. 2015. Jumlah Sel Goblet pada Usus Halus Ayam Kampung (Gallur domesticus) yang Terinfeksi Ascaridia galli secara Alami. Jurnal Medika Veterinaria, 9(1): 1-6.

Chaudhary, K., and E. Adamson. 2016. The Prime Prepare and Repair Your Body for Spontaneous Weight Loss. Harmony Books. USA.

Cotran, R.S., V. Kumar, and T. Collins. 2003. Pathology Basic of Disease 6th ed. WB Saunders Co. Philadelphia, 3(2): 20-21. 
Geboes, K. 2003. Histopathology of Crohn's Disease and Ulcerative Colitis. Journal of Pathology, 11(18): 255-276.

Hongwei, Q., A.W. Cynthia, J.L. Sun, Z. Xueyan, and N.B. Etty. 2005. LPS Induces CD4 Genes Expression Through The Activation of NF-kB and STAT-1a In Macrophage and Microglia. Blood, 106(9): 3114-3122.

Kumar, V., Abbas, and A.K. Aster. 2013. Robbins Basic Pathology. Elsevier Saunders. Philadelphia, USA.

Malone, L. K., K. R. Fletcher, and L. M. Plank. 2014. Advanced Practice Nursing in the Care of Older Adults. Davis Company. Philadelphia.

Manning, S. D. 2010. Deadly Diaseases and Epidemics; Escherichia coli Infections Second Edition. Chelsea House Publishing. USA.

Ogunseitan, O., and P. Robbins. 2011. Acute Gastroenteritis. Sage Publications. USA.

Prakash, A. 2001. Antioxidant Activity. Medallion Laboratories Analitical Progress, 19(2): 16-23.

Pringgoutomo, S., H. Sutisna dan A. Tjarta. 2002. Buku Ajar Patologi 1. UI Press. Jakarta.

Repetto, M., J. Semprine dan A. Boveris. 2012. Lipid Peroxidation Chemical Mechanism, Biological Implications and Analytical Determination. Dalam Lipid Peroxidation, Angel Catala (Ed), InTech, DOI:10.5772/45943.

Sanders, M.J. 2012. Mosby's Paramedic Textbook Fourth Edition. Jones \& Barlett Learning. USA.

Short, M.A. 2004. Linking the sepsis triad of inflammation, coagulation, and supressed fibrinolysis to infants. Ads Neonatal Care, 11(5)258-73.
Pengembangan Peternakan: Harapan Vaksin E. coli Enterotoksinogenik, Enteropatogenik, dan Verotoksigenik Isolat Lokal untuk Pengendalian Kolibasilosis Neonatal. Balai Penelitian Veteriner. Bogor.

Suryohudoyo, P. 2000. Oksidan, Antioksidan dan Radikal Bebas. Ilmu Kedokteran Molekuler. Sagung Seto. Jakarta. 3146.

Utami, W. 2007. Daya Hambat Ekstrak Daun Dewandaru (Eugenia uniflora L.) Terhadap Aktivitas GST Kelas PI Ginjal Tikus Secara In Vitro. Universitas Muhammadiyah Surakarta. Jurnal Penelitian Sains \& Teknologi, 8(2): 110118.

Utami, W., M. Da'i, dan Y.S. Sofiana,. 2005. Uji Aktivitas Penangkap Radikal dengan Metode DPPH serta Penetapan Kandungan Fenol dan Flavonoid dalam Ekstrak Kloroform, Ekstrak Etil Asetat, Ekstrak Etanol Daun Dewandaru (Eugenia uniflora L.). Pharmacon, 6 (1): 59

Watson, R. R. 2015. Modulation of Sleep by Obesity, Diabetes, Age, and Diet. Elsevier. USA.

Watson, R. R., and V. R. Preedy. 2013. Bioactive Food As Interventions for Arthritis and Related Inflammatory Diseases. Elsevier. UK.

Yunus, M. 2001. Pengaruh Antioksidan Vitamin C terhadap MDA Eritrosit Tikus Wistar Akibat Latihan Anaerobik. Jurnal Pendidikan Jasmani,9(1): 9-16.

Supar. 2001. Pemberdayaan Plasma Nutfah

Mikroba Veteriner dalam

(c)2020. Fajeria et al. Open access under CC BY - SA license, doi: 10.20473/mkh.v31i2.2020.74-84 Received: 29-03-2020, Accepted: 10-05-2020, Published online: 29-05-2020

Available at https://e-journal.unair.ac.id/MKH/index 